\title{
Influence of short- and long-term
} administration of Melengestrol acetate on estrus activity and reproductive performance of nulliparous Barki ewes

\author{
Farrag, B.; Abd El-Hamid, I.S.; El-Hawy, A.S.; El-Bassiony, M.F.; \\ El-Rayes, M.A.H. and Shedeed, H.A.
}

\author{
Animal and Poultry Physiology Department, Animal and Poultry Production Division, \\ Desert Research Center, Cairo, Egypt \\ Corresponding author:moharramf@yahoo.com
}

\begin{abstract}
In Egypt, research focusing on estrous synchronization in small ruminants based on Melengestrol acetate (MGA) supplementation, particularly in nulliparous ewes, is still lacking. The present work aimed to evaluate effect of long-term and short-term administration of melengestrol acetate (MGA) treatments on estrus synchronization and reproductive performance of nulliparous Barki Ewes. This study was performed in Siwa Oasis Research Station (Tegzerty Experimental Farm for animal production), belonged to Desert Research Center, Egypt. Forty five nulliparous Barki ewes with age ranging from 15.5 to 16.5 months, and $38 \pm 0.23 \mathrm{~kg}$ average live body weight were assigned to one of three groups: (1) control $(C, n=15)$; (2) longterm treatment with MGA $(n=15,0.22 \mathrm{mg} /$ ewe/d for 14 days) and (3) short-term treatment with MGA ( $n=15$, $0.22 \mathrm{mg} / \mathrm{ewe} / \mathrm{d}$ for 7 days). At the end of MGA treatment (14 or 7 d) all treated ewes were injected by $600 \mathrm{IU}$ PMSG intramuscularly. The results showed that, ewes treated with MGA exhibited highest $(P<0.05)$ estrus response rate (100\%) in short term-MGA, followed by long term-MGA (93.33\%), whereas the lowest was observed in control group (80\%). Conception rates after natural mating were $85.71 \%$ and $93.33 \%$ for long term and short term MGA treated ewes, respectively. However, it recorded $100 \%$ in the control group. Fertility rate was significantly the highest $(P<0.05)$ in short term-MGA $(93.33 \%)$ than other groups $(73.33 \%)$. There were no significant differences $(p>0.05)$ in terms of lambing rate and prolificacy among the control and treated ewes. In the meantime, mean values of serum estradiol 17- $\beta$ were lower $(P \leq 0.01)$ in long-term treated ewes compared to those of short-term treated ones (27.20 \pm 1.78 , $32.67 \pm 1.27 \mathrm{pg} / \mathrm{ml})$, respectively, while the lowest $(P<0.05)$ level was recorded in the control ewes $(13.01 \pm 1.31$ $\mathrm{pg} / \mathrm{ml}$ ). Furthermore, overall mean values of serum
\end{abstract}

progesterone in the control group $(1.32 \pm 0.09 \mathrm{ng} / \mathrm{ml})$ was higher $(P<0.05)$ than those oflong-and short-term MGA treated groups $(1.01 \pm 0.13,0.92 \pm 0.11, \mathrm{ng} / \mathrm{ml})$, respectively. It is concluded that reproductive efficiency of nulliparous Barki ewes could be improved by shortterm supplementation with MGA.

Keywords- Melengestrol acetate (MGA), Estrus synchronization, Reproductive performance, Barki ewes.

\section{INTRODUCTION}

Despite growing evidence of applicability of estrus synchronization approach in pluriparous ewes, limited information is available for exploiting this technique in nulliparous ewes. The reduction of age at first delivery is a major goal for modern small ruminant's production systems (Bandeira et al., 2004). However, it is necessary to understand reproductive behavior of nulliparous ewes. The first estrus in ewes varies according to several factors such as breed and period of the year born, while fertility of nulliparous ewes is associated with live weight, body condition score, sanitary management and nutritional status (Aktaset al., 2015). Hormonal treatment to control ovulation and reproduction is a prerequisite for successful breeding and increasing the number of pregnant females (Motlomelo et al., 2002).

In ewes, progestagens are widely used to synchronize estrus, and typically result in approximately $90 \%$ estrus exhibition within a 24-hour period and conception rate of $70-80 \%$ (Evans et al., 2001). Among the various methods or biotechnologies, which can be employed to control the reproductive cycle of the ewes is the use of synthetic progestins, like melengestrol acetate (MGA), which represents an ideal choice for this type of production in rural areas, where the farmers do not have the economic resource and sufficient technology (Álvarez 
and Ducoing, 2005). MGA is a low cost product, easy to administer (can be mixed with feed) and does not cause abortion (Salas et al., 2011).The percentage of ewes lambing after treatment with MGA has been reported to range from 25 to $85 \%$, and appeared to depend on ewe breed (Safranski et al., 1992), length of treatment or length of breeding period (Powell et al., 1996), or use in combination with gonadotropins (Morrical et al., 1995).

Melengestrol acetate is attractive to sheep farmers, because the cost of treatment is much less than that associated with the use of intravaginal sponges. The most costly component of the traditional out-of-season breeding strategy is eCG/PMSG. Some research has called into question the requirement for stimulation of follicles with eCG. If the use of eCG proved to be unnecessary, it would markedly alter the economics of out-of-season breeding programs. Due to the limited understanding of nulliparous reproduction, the current work was conducted to evaluate effect of long-term and short-term Melengestrol acetate treatments on estrus synchronization response and reproductive performance of nulliparous Barki ewes.

\section{MATERIALS AND METHODS}

This study was carried out at Siwa Oasis Research Station (Tegzerty Experimental Farm for Animal Production), which belongs to Desert Research Center, Ministry of Agriculture and Land Reclamation, Egypt. Which lies between longitudes (Lat: $29^{\circ} 06^{\prime \prime} 29^{\circ}$ 24" N Long: $\left.25^{\circ} 16^{\prime \prime} 26^{\circ} 12^{\prime \prime} \mathrm{E}\right)$ ), and located $330 \mathrm{Km}$ southwest of the Mediterranean shoreline and at $65 \mathrm{Km}$ east of the Libyan borders. All animal were kept in semiopen pens roofed with wood throughout the experimental period (April 2016 - February 2017).

\section{Animal's management}

Forty five nulliparous Barki ewes, aged $15.5-$ 16.5 months and average body weight of $38 \pm 0.23 \mathrm{~kg}$ were used. Animals were fed a concentrate mixture according to their body weight requirements (NRC, 1985). Of the mixture contained crude protein not less than $14 \%$, crude fiber not less than $15 \%$, ash not more than $9 \%$, crude fat not less than $2 \%$, total digestible matter not less than 65\%, and Egyptian clover (Trifolium alexandrinum) hay as a roughage ration ad libitum. Fresh water was available to all groups daily. All animals were clinically examined and were found to be free of any disease or reproductive disorders.

\section{Experimental design}

The ewes were equally divided into three groups: The first group: $(n=15)$ served as control. The second group: MGA long-term protocol (Long-Term. $\mathrm{n}=$ 15) received $0.22 \mathrm{mg} / \mathrm{head} /$ day Melengestrol acetate $\left(\mathrm{MGA}^{\circledR} 200\right.$ Premix NDC 0009-0952-01, Upjohn Company; Michigan, USA) for 14 days. The Third group: MGA short-term protocol (Short-Term. $n=15$ ) received the same MGA concentration for 7 days. At the end of MGA treatment (14 or 7 d) all ewes were injected by 600 IU pregnant mare serum gonadotropin PMSG i.m (Gonaser, Laboratories HIPRA, S. A.-Avoda. Laselva, 13517170 Amer (GIRONA), Spain.), and were exposed to intact Barki rams (1 ram per 15 ewes) fitted with a marking harness with rotation for a 17-day breeding period in the control group, and 4 days in the treated groups. The chemical composition of (MGA) is presented in Table (1).

Table.1: Chemical composition of Melengestrol acetate 200 Premix (MGA).

\begin{tabular}{|l|c|}
\hline Ingredients & Concentration \\
\hline Inactive & \\
\hline Soybean hulls & $96 \%$ \\
\hline Starch & $2.98 \%$ \\
\hline Mineral Oil & $1 \%$ \\
\hline Active & $200 \mathrm{mg} / \mathrm{kg}$ \\
\hline Melengestrol Acetate & \\
\hline
\end{tabular}

\section{Blood samples}

Blood samples were collected from the jugular veins of all animals into non-heparinized vacationer tubes at MGA withdrawal (day 7 or $14,0 \mathrm{hr}$.) and at 24, 48, 72, and $96 \mathrm{~h}$ after injection of PMSG. Blood samples were centrifuged at $3000 \mathrm{rpm}$ for 20 minutes, and serum was aspirated and kept at $-20{ }^{\circ} \mathrm{C}$ until analysis.

\section{Hormonal and serum biochemical analysis}

Serum progesterone $\left(\mathrm{P}_{4}\right)$ and estradiol 17- $\beta\left(\mathrm{E}_{2}\right)$ concentrations were analyzed using commercial ELISA kits (Monobind, USA) according to Abraham (1981). The intra -and inter-assay CV's are (9.3, $9.7 \%$ and 8.2, 95\%), respectively. Concentrations of cholesterol (CHO), and Glucose (Glu) were determined using colorimetric kits (Diamond Diagnostic, Egypt). 


\section{Statistical analysis}

A General Linear Model procedure (SAS, 2004) was used for the statistical analyses of serum biochemical parameters and serum hormones concentrations at hours $0,24,48,72$ and 96 using the following model:

$\mathrm{Y}_{\mathrm{ijk}}=\mu+\mathrm{T}_{\mathrm{i}}+\mathrm{H}_{\mathrm{j}}+\mathrm{TH}_{\mathrm{ij}}+\mathrm{e}_{\mathrm{ijk}}$

Where,

$\mathrm{Y}_{\mathrm{ijk}}=$ Any observation of $\mathrm{k}^{\text {th }}$ animal within $\mathrm{i}^{\text {th }}$ treatment within $\mathrm{j}^{\text {th }}$ hour

$\mu \quad=$ Overall mean

$\mathrm{T}_{\mathrm{i}} \quad=$ Effect of $\mathrm{i}^{\text {th }}$ treatment $(\mathrm{i}=1-3)$

$\mathrm{H}_{\mathrm{j}} \quad=$ Effect of $\mathrm{j}^{\text {th }}$ hour $(\mathrm{j}=1-5)$

$\mathrm{TH}_{\mathrm{ij}}=$ The interaction between treatment and hour

$\mathrm{e}_{\mathrm{ijk}}=$ Experimental error

Another General Linear Model procedure (SAS, 2004) was used for the statistical analysis of birth and weaning weights and average daily gain for lambs using the following model:

$Y_{i j}=\mu+T_{i}+e_{i j}$

Where,

$\mathrm{Y}_{\mathrm{ij}}=$ Any observation of $\mathrm{j}^{\text {th }}$ animal within $\mathrm{i}^{\text {th }}$ treatment

$\mu \quad=$ Overall mean

$\mathrm{T}_{\mathrm{i}} \quad=$ Effect of $\mathrm{i}^{\text {th }}$ treatment $(\mathrm{i}=1-3)$

$\mathrm{e}_{\mathrm{ij}}=$ Experimental error

Significant differences among means were detected using Duncan's multiple range test (Duncan, 1955). While, reproductive traits (estrus response), (conception, lambing, fertility, prolificacy, mortality and weaning rates) and sex ratio were analyzed using Chisquare test.

\section{RESULTS AND DISCUSSION \\ Reproductive performance:}

Little research has been focused on estrus synchronization in Egyptian sheep using MGA, and no results could be found on the feeding with MGA for synchronization purpose in nulliparous ewes. The results show that estrus synchronization can be done succes sfully in nulliparous Barki ewes with MGA (Table 2).

The short-term group (7 days) showed the highest percentage of ewes responded to estrus synchronization $(100 \%)$ followed by long-term group (14 days) $(93.33 \%)$ and control group (80\%). Findings of estrus rates were in agreement with previous results reported by (Powell et., al 1996) who reported that estrus response of ewes treated with MGA for 8 days (shortterm) was $90 \%$, while was $92.3 \%$ in ewes treated with MGA for 14 days (long-term). In another study, Windorski et al. (2008) reported that treatment with MGA $(0.3 \mathrm{mg} /$ ewe $/ \mathrm{d})$ for 7 days increased the proportion of Rambouillet ewes displaying estrus by 5-20\%. Later, Rojo and Salas (2015) evaluated the effect of long-term (17 days) MGA treatment on the induction and synchronization of estrus in ewes and observed that $95 \%$ of the females exhibited estrus. Likewise, Salas et al. (2011) obtained 100\% ewes in estrus using MGA for 17 days, which was quite the opposite of what Emsen et al. (2011) reported (89\% of ewes in estrus using $0.125 \mathrm{mg}$ MGA for 12 days (long term) and 62\% of ewes in estrus using $0.125 \mathrm{mg}$ of MGA for 9 days (short term)), this difference of results in both studies may be due to the difference in dose of MGA which was half the dose used in this study.

Table.2: Reproductive efficiency of nulliparous Barki Ewes following long-term and short-term protocols of Melengestrol acetate treatment $(L S M \pm S E)$.

\begin{tabular}{|l|c|c|c|}
\hline \multirow{2}{*}{ Traits } & Control & Long term-MGA & Short term-MGA \\
\cline { 2 - 4 } & $\mathrm{N}=15$ & $\mathrm{~N}=15$ & $\mathrm{~N}=15$ \\
\hline Estrus response rate (\%) & $80^{\mathrm{b}}$ & $93.33^{\mathrm{ab}}$ & $\left(100^{\mathrm{a}}\right.$ \\
& $(12 / 15)$ & $(14 / 15)$ & $93.33^{\mathrm{a}}$ \\
\hline Conception rate (\%) & $100^{\mathrm{a}}$ & $85.71^{\mathrm{a}}$ & $(14 / 15)$ \\
& $(12 / 12)$ & $(12 / 14)$ & $100^{\mathrm{a}}$ \\
\hline Lambing rate (\%) & $91.67^{\mathrm{a}}$ & $91.67^{\mathrm{a}}$ & $(14 / 14)$ \\
\hline Fertility rate (\%) & $(11 / 12)$ & $(11 / 12)$ & $93.33^{\mathrm{a}}$ \\
\hline Prolificacy rate (\%) & $73.33^{\mathrm{b}}$ & $73.33^{\mathrm{b}}$ & $100^{\mathrm{a}}$ \\
\hline
\end{tabular}

a-b values within the same row with different letters differ $(\mathrm{P}<0.05)$.

Estrus response $=$ number of ewes showing signs of estrus/total ewes treated $\mathrm{x} 100$.

Conception rate $=$ number of ewes conceived $/$ number of ewes showing estrus and mated $\mathrm{x} 100$.

Lambing rate $=$ number of ewes lambed $/$ number of ewes mated x100.

Fertility rate $=$ number of ewes lambed/total ewes treated $\mathrm{x} 100$.

Prolificacy rate $=$ number of lambs born/number ewes lambed x100. 
The conception rate (Table 2) was higher (100\%) in control group than groups treated with MGA (85.71 and $93.33 \%$ ) in long and short term groups, respectively. The high pregnancy rate observed in the control group could be due to the percentage of ewes pregnant to the number of ewes which showed signs of estrus, which was further lower among groups. In this study conception rates in groups treated with MGA are much higher than those observed by Emsen et al. (2011), who reported that conception rate was $44 \%$ in ewes treated with MGA for 12 days (long-term) and $41 \%$ in ewes treated with MGA for 9 days (short-term). Findings of pregnancy rates were in disagreement with results reported by Keefe and Wichtel (2000) when naturally-mated ewes were treated with MGA with and without PMSG administration. The later authors obtained pregnancy rates of $43.3 \%$ and $31 \%$ for the aforementioned groups, respectively. (Salas et al., 2011) reported that the conception rate in the experimental group with $0.45 \mathrm{mg}$ MGA/head/day for 17 days was $70 \%$ compared with $50 \%$ in control group. This result was higher than those obtained by Powell et al (1996), who reported that lambing rate of ewes treated with MGA for 8 days (short-term) was $60 \%$, while was $57.7 \%$ in ewes treated with MGA for 14 days (long-term).

Results of the present study demonstrated that lambing rate (Table 2) ranged between 91.67 to $100 \%$ and was numerically higher in short-term group (100\%) than other groups $(91.67 \%)$, but with no significant differences. Our results of lambing rate were higher than those obtained in control, MGA and MGA+PG 600 groups (14.8, 40.5 and $41.2 \%$, respectively) according to Safranski et al. (1992). But close to those obtained by (Windorski et al., 2008) who found that lambing rate in Rambouillet ewes was $80.4,77.8$ and $80.4 \%$ in control, MGA and MGA+PG-600, respectively. On the other side, Powell et al. (1996) compared 8, 11 and 14 days of MGA supplementation on lambing rates in out of season breeding programs and they concluded no difference. Based on these observations and the economics of using the product for a shorter period of time, they concluded that an 8-day course of treatment was best.

Fertility rate (Table 2) was found to be 73.33 , 73.33 and $9.33 \%$ in the control, long and short terms groups, respectively $(\mathrm{P}<0.05)$. This result was higher than those obtained by Emsen et al. (2011) who recorded fertility percentage of $45 \%$ when Morkaraman ewes were treated with $0.125 \mathrm{mg}$ MGA/ewe/day for 12 days, whereas Castonguay et al. (2002) used $0.4 \mathrm{mg}$ MGA/ewe/day during 10 days and obtained fertility rate of $45 \%$. In both studies, the low fertility rate may be due to when low doses are administered, MGA $(\leq 0.12 \mathrm{mg})$ generates a high frequency of luteinize hormone (LH) pulses, triggering the development of persistent follicles (Colazo et al., 2007), while when high doses are administered ( $\geq$ $0.4 \mathrm{mg}$ ), $\mathrm{LH}$ suppression can be so intense to the extent which inhibits follicular development (Lopez et al 2007). It is recommended that the dose of $0.22 \mathrm{mg}$ of MGA/ewe/day for 7 days (short-term) is administered, in order to get the best response in the lambing rate $(100 \%)$ and fertility rate $(93.33 \%)$ of nulliparous Barki ewes.

The percentage of prolificacy obtained was 1.0 lamb born by ewe for all groups and there was no significant difference among the groups. In this study, prolificacy rate (number of lambs born/number of ewes lambing) did not different among groups which were 1.0 in the three groups and therefore the use of PMSGhad no effects on increasing lambs born. This opinion is consistent with what Safranski et al. (1992) reported, the number of lambs born per ewe lambing (prolificacy rate) was not different among treatments or genotypes. Consequently, the advantage that was obtained in ovulation rate through the use of PG-600 was not realized at lambing, although the number of luteal structures increased when PG- 600 was injected on the last day of feeding MGA, the number of lambs born per ewe was not significantly affected. In another work, Windorski et al (2008) reported that no significant differences of lambs born per ewe lambing between treated and untreated groups with MGA, where was 1.82, 1.91 and 1.89 for control, MGA and MGA+PG600, respectively. In that regard, Keefe and Wichtel (2000) reported that no significant differences of lambs born per ewe lambing between treated ewes with MGA with and without eCG and mated naturally, prolificacy rates were $1.46 \%$ and $1.66 \%$, respectively.

\section{Serum Estradiol 17- $\beta \quad\left(\mathbf{E}_{2}\right)$ and progesterone $\left(\mathbf{P}_{4}\right)$ concentrations:}

Changes in serum estradiol $17-\beta$ and progesterone concentrations in ewes are presented in Figure 1(A and B, respectively).

Overall mean of serum estradiol 17- $\beta$ concentration were lower $(\mathrm{P} \leq 0.01)$ in long-term than in short-term groups $\quad(27.20 \pm 1.78, \quad 32.67 \pm 1.27 \mathrm{pg} / \mathrm{ml}$, respectively) and compared with control $(13.01 \pm 1.31$ $\mathrm{pg} / \mathrm{ml})$. There was no effect or interaction between treatments and hours of synchronization $(0,24,48,72$ and 96) after MGA withdrawal (figure 1). similar results were also obtained in camels (Abd El-Hamid et al., 2016), beef heifers (Funston et al., 2002), and ewes (Martínez et al., 2017; Rojo and Salas, 2015; Powell et al., 1996).The changes in serum estradiol 17- $\beta$ concentration observed in the present study are clearly attributed to the changes in ovarian kinetics in both MGA-treated groups compared with control during the synchronization period. 

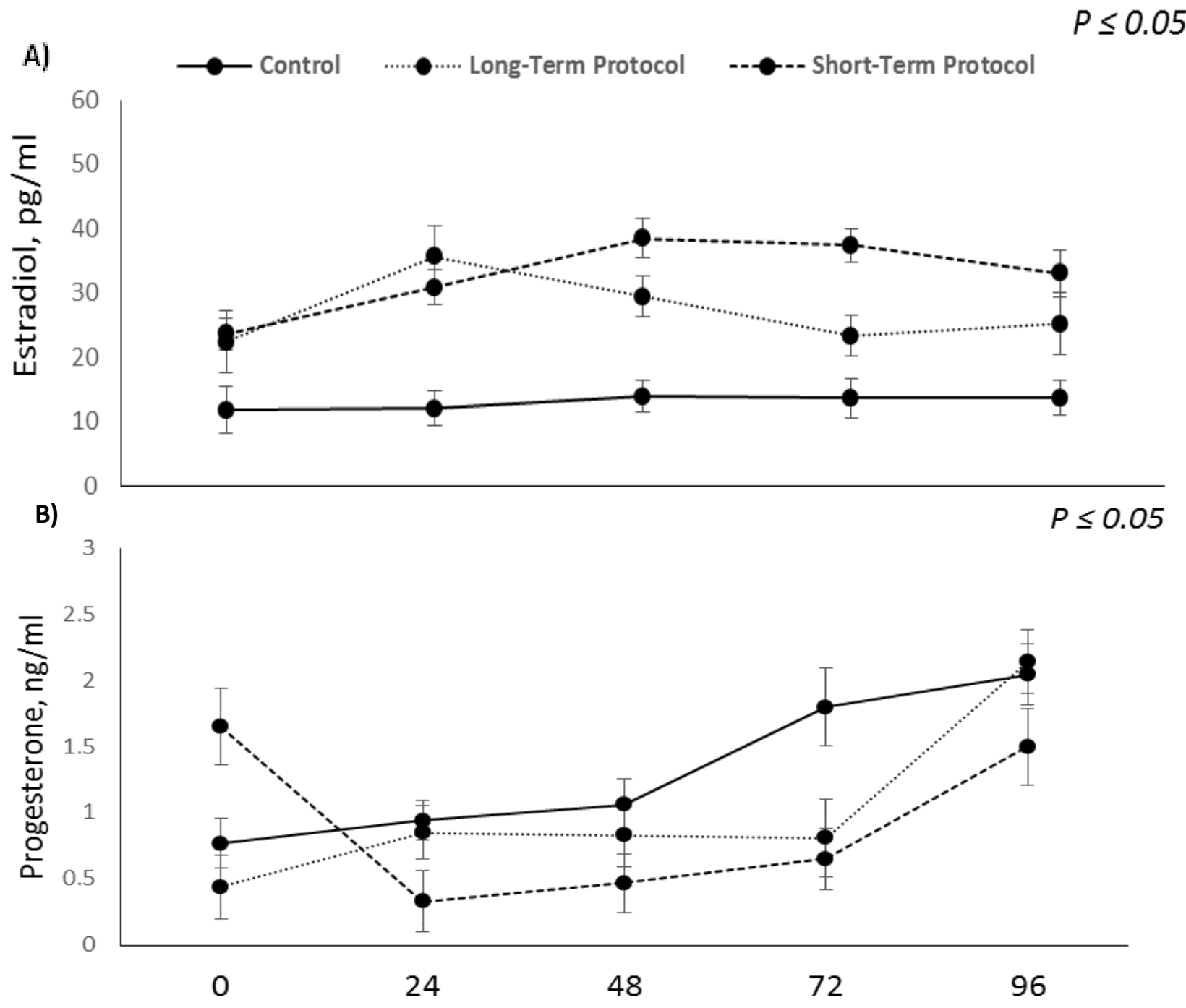

Fig.1: Concentrations of serum estradiol $-17 \beta(\mathrm{pg} / \mathrm{ml})$ (A) and progesterone (ng/ml) (B) after MGA feeding at hours of 0, 24, 48, 72 and 96 of synchronization period in nulliparous Barki ewes.

Progestin treatments inhibited the ovarian growth of newer follicles and thereby slightly decreased estradiol concentration during the long or short-term (7 or 14) days of MGA feeding. Serum estradiol increased at after withdrawal of MGA feeding (Jabbar et al., 1994).

In the present study, overall means of serum progesterone concentrations in the control group (1.32 \pm $0.09 \mathrm{ng} / \mathrm{ml})$ was higher $(\mathrm{P}<0.05)$ than those of long- and short-term MGA groups $(1.01 \pm 0.13,0.92 \pm 0.11, \mathrm{ng} / \mathrm{ml})$ respectively. There were interactions $(\mathrm{P}<0.01)$ between treatment and hours of synchronization. Serum P4 concentrations in the control and MGA-fed animals were affected by time during the experimental period. However, in progestin groups serum progesterone declined $(0.47 \pm 0.22, \quad 0.83 \pm 0.24 \mathrm{ng} / \mathrm{ml})$ compared with control at $48 \mathrm{~h}$ of synchronization period, and increased at 96 hrs., while serum progesterone elevated in control group during synchronization period (Figure 1). It seems that MGA did not increase the natural progesterone in the peripheral circulation after withdrawal; however, it mimicked its function on synchronizing ovarian activities. This, in turn, should induce follicular growth, accelerate ovum development and therefore lower concentration of progesterone (Thompson et al., 1990; Scudamore et al., 1992), while the increased of serum progesterone in control group may be due to variations in ovarian activity.

\section{Productive traits:}

From Table (3), there were no significant differences among the experimental groups in birth weight, mortality rate, weaning rate, weaning weight and average daily gain of nulliparous ewes following both long-term and short-term MGA treatment. All groups in this study had almost the same birth weight being 2.94 , 2.97 and $2.65 \mathrm{~kg}$, for control, long and short term groups, respectively. These results were in agreement with those reported by Windorski et al. (2008) who concluded that no significant differences were observed between groups 
treated and untreated with MGA, where lambs birth weights were $4.6,4.6$ and $4.7 \mathrm{~kg}$ for control, MGA and MGA+PG600, respectively. Also, weaning weights at the three months of age were $16.7,16.6$ and $16.2 \mathrm{~kg}$ in the same groups, respectively. Average daily gain in control, long- and short-term groups was estimated to be 153,151 and $150 \mathrm{~g}$, respectively. Mortality rate from birth until weaning in control, long- and short-term groups were $9.09,0.0$ and $7.14 \%$, respectively. The fit weaning rates were $90.91,100$ and $92.86 \%$ in control, long and short terms groups, respectively. There was no significant difference in sex ratio of lambs among the three groups.

Table.3: Productive performance of nulliparous Barki lambs following long-term and short-term protocols of Melengestrol acetate treatment ( $L S M \pm S E)$.

\begin{tabular}{|l|c|c|c|}
\hline Traits & Control & Long-Term-MGA & Short-Term-MGA \\
\hline Birth weight (kg.) & $2.94^{\mathrm{a}}$ & $2.97^{\mathrm{a}}$ & $2.65^{\mathrm{a}}$ \\
(Lambs N) & $(11)$ & $(11)$ & $(14)$ \\
\hline Weaning weight (Kg) & $16.70^{\mathrm{a}}$ & $16.60^{\mathrm{a}}$ & $16.20^{\mathrm{a}}$ \\
(lambs N) & $(10)$ & $(11)$ & $(13)$ \\
\hline Average daily gain (g) & $0.153^{\mathrm{a}}$ & $0.151^{\mathrm{a}}$ & $0.150^{\mathrm{a}}$ \\
\hline Mortality rate & $9.09^{\mathrm{a}}$ & $0.00^{\mathrm{a}}$ & $7.14^{\mathrm{a}}$ \\
\hline Weaning rate & $90.91^{\mathrm{a}}$ & $100^{\mathrm{a}}$ & $92.86^{\mathrm{a}}$ \\
\hline Sex ratio (M/F) & $54.55^{\mathrm{a}}$ & $45.45^{\mathrm{a}}$ & $57.14^{\mathrm{a}}$ \\
& $45.45^{\mathrm{a}}$ & $54.55^{\mathrm{a}}$ & $42.86^{\mathrm{a}}$ \\
\hline
\end{tabular}

${ }^{a-d}$ values within the same row with different letters differ $(\mathrm{P}<0.05)$.

Weaning rate $=$ number of lambs weaned $/$ number of lambs born x100

\section{Serum biochemical parameters:}

Overall means of glucose (Glu) concentrations decreased $(\mathrm{P} \leq 0.01)$ in both treated groups $(69.86 \pm 2.12$, $71.96 \pm 1.62 \mathrm{mg} / \mathrm{dl}$, respectively) compared with control $(79.79 \pm 1.82 \mathrm{mg} / \mathrm{dl})$. There were interactions $(\mathrm{P} \leq 0.01)$ between treatment and hours. Serum glucose concentrations were not affected by time $(0,24,48,72$ and 96) (Table 4). These data are in agreement with those reported by Abd El-Hamid et al. (2016) and El-Sherif and Assad (2001). In our results the decreased glucose concentrations with increased ovarian activity during synchronization period may be due to the uptake of glucose by ovarian tissues (Rabiee and Lean 2000).

Also, overall means of cholesterol (Cho) concentrations decreased $(\mathrm{P} \leq 0.01)$ in MGA-treated groups (107.19 \pm 4.47 and $108.96 \pm 3.92 \mathrm{mg} / \mathrm{dl})$ compared with control $(138.13 \pm 4.06 \mathrm{mg} / \mathrm{dl})$. However, no interactions were detected between treatment and hours. Also serum cholesterol concentrations were not affected by time $(0,24,48,72$ and 96$)$ (Table 2$)$. The same results were previously reported by Al-Bulushi et al. (2017) and Egbe-Nwiyi et al. (2015) in goats and sheep (Kandiel et al., 2016) during both synchronization and estrous period. Cholesterol is the precursor of the production of steroids hormone such as estrogens during ovarian activity (Arther et al., 1982).

\section{CONCLUSION}

Our results of estrus response, fertility and lambing rates following melengestrol acetate (MGA) elucidate its efficiency when applied in nulliparous ewes. Additionally, MGA is a low-cost substance which makes it a convenient alternative to hormonal treatments when applying estrus synchronization protocols on a large scale. In conclusion, estrus can be synchronized and improving reproductive performance in nulliparous Barki ewes by using short-term MGA treatment (0.22 $\mathrm{mg} / \mathrm{ewe} / \mathrm{day}$ for 7 days ).

\section{ACKNOWLEDGMENTS}

Our sincere thanks to Prof. Dr. Gamal EL-Din A. Hassan, professor of animal physiology - Faculty of Agriculture - Alexandria University, and Prof. Dr. Samir Z. E -Zarkouny, professor of animal physiology Faculty of Agriculture - Alexandria University, for providing materials (Melengestrol acetate, MGA). 
Table 4. Changes in serum glucose and cholesterol concentrations during synchronization period in nulliparous of Barki ewes (Mean \pm SE).

\begin{tabular}{|c|c|c|c|c|c|c|c|}
\hline \multirow{2}{*}{ Parameters } & \multirow{2}{*}{ Treatment } & \multicolumn{5}{|c|}{ Hours } & \multirow[t]{2}{*}{ Overall } \\
\hline & & 0 & 24 & 48 & 72 & 96 & \\
\hline \multirow{5}{*}{ Glucose $(\mathrm{g} / \mathrm{dl})$} & Control & $64.05 \pm 3.71^{\mathrm{d}}$ & $81.09 \pm 3.71^{\mathrm{abc}}$ & $89.90 \pm 3.71^{\mathrm{a}}$ & $83.14 \pm 4.76^{\mathrm{ab}}$ & $80.26 \pm 4.18^{\mathrm{abc}}$ & $79.79 \pm 1.82^{\mathrm{A}}$ \\
\hline & Long-term & $72.44 \pm 4.07^{\mathrm{bcd}}$ & $64.63 \pm 5.56^{\mathrm{d}}$ & $66.51 \pm 4.70^{d}$ & $73.28 \pm 4.70^{\mathrm{bcd}}$ & $72.60 \pm 4.70^{\mathrm{bcd}}$ & $69.86 \pm 2.12^{\mathrm{B}}$ \\
\hline & Short-term & $78.03 \pm 3.78^{\mathrm{abc}}$ & $66.06 \pm 3.44^{\mathrm{d}}$ & $69.31 \pm 3.78^{\mathrm{cd}}$ & $70.94 \pm 3.44^{\text {bcd }}$ & $75.49 \pm 3.78^{\mathrm{bcd}}$ & $71.96 \pm 1.62^{\mathrm{B}}$ \\
\hline & Overall & $71.51 \pm 2.22$ & $70.59 \pm 2.50$ & $75.24 \pm 2.22$ & $75.79 \pm 2.50$ & $76.11 \pm 2.44$ & \\
\hline & Control & $138.60 \pm 8.86$ & $136.24 \pm 8.86$ & $137.83 \pm 8.86$ & $141.51 \pm 8.86$ & $136.47 \pm 9.90$ & $138.13 \pm 4.06^{\mathrm{A}}$ \\
\hline \multirow{3}{*}{$\begin{array}{l}\text { Cholesterol } \\
\text { (g/dl) }\end{array}$} & Long-term & $111.23 \pm 9.70$ & $104.80 \pm 9.70$ & $106.83 \pm 9.70$ & $105.85 \pm 11.12$ & $107.23 \pm 9.70$ & $107.19 \pm 4.47^{\mathrm{B}}$ \\
\hline & Short-term & $106.81 \pm 8.20$ & $105.69 \pm 8.20$ & $112.12 \pm 9.07$ & $106.85 \pm 9.02$ & $113.36 \pm 9.07$ & $108.96 \pm 3.92^{\mathrm{B}}$ \\
\hline & Overall & $118.88 \pm 5.16$ & $115.58 \pm 5.16$ & $118.93 \pm 5.32$ & $118.07 \pm 5.61$ & $119.02 \pm 5.52$ & \\
\hline
\end{tabular}

\footnotetext{
${ }^{\mathrm{a}-\mathrm{d}}$ values within the same row with different letters differ $(\mathrm{P}<0.05)$.

$A, B$ values within the same column with different letters differ $(\mathrm{P}<0.05)$.
} 


\section{REFERENCES}

[1] Abd El-Hamid, I.S., Nour El-Din, A.N.M., Zaghloul, A.A. El-Bahrawy, K.A., Elshahaw, I.I., Allam A.M., EL-Zarkouny, S.Z. and. Hassan, G.A. (2016). Effects of calcium salts of fatty acids rich in palmitic and oleic fatty acids on reproduction and serum biochemistry in Barki ewes. Small Rumin. Res., (144): 113-118.

[2] Abraham, G.E., 1981. The application of natural steroid radioimmunoassay to gynecologic endocrinology. In: Abraham GE, editor. Radioassay Systems in Clinical Endocrinology, Basel: Marcel Dekker, pp: 475-529.

[3] Aktas, A. H.; Dursun, S.; Dogan, S.; Kiyma, Z.; Demirci, U. and Halici, I. (2015). Effects of ewe live weight and age on reproductive performance, lamb growth, and survival in Central Anatolian Merino sheep. Arch. Anim. Breed., 58:451-459.

[4] Al-Bulushi, S., Shawaf, T. and Al-Hasani, A. (2017). Some hematological and biochemical parameters of different goat breeds in Sultanate of Oman "A preliminary study. J. Vet. World. (10): 461-466.

[5] Álvarez, R. L., and Ducoing, W. A. (2005). Reproductive Aspects of Sheep and Goats. Faculty of Medicine Veterinary and Zootechnics, National Autonomous University of Mexico. Accessed June, 2014.

http://amaltea.fmvz.unam.mx/textos/escrito_Repro.p df.

[6] Arther, G.H., Noakes, D.E. and Pearson, H. (1982). Veterinary Reproduction and Obstetrics. 5th (Ed.) Bailliere Tindall, London.

[7] Bandeira, D. A., Santos, M. H. B., Correia, Neto J. and Nunes, J. F. (2004). Aspectos gerais da caprinoovinocultura no Brasil e seus reflexos produtivo e reprodutivo. In: Santos M H B, Oliveira M A L and Lima P F (Eds). Diagnóstico de gestação na cabra e na ovelha. São Paulo: Varela, pp.1-8.

[8] Castonguay, F., Leduc, G., and Goulet, G. (2002). Use of Melengestrol for Estrus Synchronization in an Artificial Insemination Program in Ewe. Journal Animal Science 80: 268-9.

[9] Colazo, M. G., Mapletoft, R. J., Martínez, M. F., and Kastelic, J. P. (2007). The Use of Treatments Hormonal (MGA) to Synchronize Oestrus and Ovulation in Heifers. Veterinary Science 9: 4-16.

[10] Duncan DB (1955). The multiple range and F- tests. Biometrics, 11: 1-42.

[11] Egbe-Nwiyi, T., Igwenagu, E. and Samson, M. (2015). The influence of sex on the haematological values of apparently healthy adult Nigerian Sahel goats. Sokoto J. Vet. Sci., (13): 54-58.
[12] El-Sherif, M.M.A. and F. Assad, (2001). Changes in some blood constituents of Barki ewes during pregnancy and lactation under semi-arid condition. Small Rumin. Res., (40): 269-277.

[13] Emsen, E., Giménez, D. C., Kutuca, M., and Koycegiz, F. (2011). "Reproductive Response of Ewes Synchronized with Different Lengths of MGA Treatments in Intrauterine Insemination Program." Animal Reproduction Science 126 (1-2): 57-60.

[14] Evans, A.C.O.; Flynn, J.D.; Quinn, K.M.; Duffy, P.; Quinn, P.; Madgwick, S.; Crosby, T.F.; Boland, M.P. and Beard, A.P. (2001). Ovulation of aged follicles does not affect embryo quality or fertility after a 14-day progestagen estrus synchronization protocol in ewes. Theriogenology 56, 923-936.

[15] Jabbar, G., Umberge, S. H. and Lewis G. S (1994). Melengestrol Acetate and Norgestomet for the Induction of Synchronized Estrus in Seasonally Anovular Ewes. J. Anim Sci.(72):3049-3054.

[16] Kandiel, M..M., El-Khaiat, H.M. and Karima, M.M. G. (2016). Changes in some hematobiochemical and hormonal profile in Barki sheep with various reproductive statuses. Small Rum. Res., (136): 8795.

[17] Keefe, G.P. and Wichtel, J.J. (2000). Evaluation of melengestrol acetate and equine chorionic gonadotropin for out-of-season breeding in sheep on Prince Edward Island. Can. Vet. J. 41, 211-214.

[18] López, A. S., González, A. B., and Carrizosa, J. A. (2007). New Estrus Synchronization and Artificial Insemination Protocol for Goats Based on Male Exposure, Progesterone and Cloprostenol. Theriogenology 68: 1081-7.

[19] Martínez, J.A. R., Piña, R. G., Caratachea, A. J., Patiño, A. B., Villavicencio, J. L. E. and Razo, G., S. (2017). Estrus, Fertility and Prolificacy in Wool Sheep Treated With Melengestrol Acetate on the Reproductive and Non-Reproductive Period. Transylvanian Review. (22):5689-5695.

[20] Morrical, D.G., Youngs, C.R. and McClain, A. (1995). The influence of MGA and PG600 on the out of season reproductive performance of ewes. Anim Sci Leaflet;R1475.

[21] Motlomelo, K.C.; Greyling, J.P.C. and Schwalbach, L.M.J. (2002). Synchronization of oestrus in goats: The use of different progestagen treatments. Small Rumin Res. 45, 45-49.

[22] NRC, 1985. Nutrition Requirements of Sheep, 6th rev. ed. National Academy Press, Washington, D.C., USA.

[23] Powell, M.R, Kips, M., Lumberton, W.R. and Keisler, D.H. (1996). Use of melengestrol acetate- 
based treatments to induce and synchronize estrus in seasonally anestrous ewes. J Anim Sci;74:2292-302.

[24] Rabiee A. R. and I. J. Lean. (2000). Uptake of glucose and cholesterol by the ovary of sheep and cattle and the influence of arterial LH concentrations. Animal Reproduction Science. (64): 199 -209.

[25] Rojo-Martínez, J., A. and Salas-Razo G. (2015). The Use of Melengestrol Acetate as a Strategy to Improve Production Efficiency of Sheep in Rural Areas in Mexico. Journal of Agricultural Science and Technology. (5): 210-213.

[26] Safranski, T.J., Lamberson, W.R. and Keisler, D.H. (1992). Use of melengestrol acetate and gonadotropins to induce fertile estrus in seasonally anestrous ewes. J Anim Sci;70:2935-41.

[27] Salas, R. G., Mata, F., Perea, M., Garcidueñas, R., Gutiérrez, E., Caratachea, A., and Flores, P. (2011). "Estrus Grouping in Sheep Treated with Melengestrol Acetate (MGA)." Journal of Agricultural Science and Technology 1 (8): 1295-6.
[28] SAS (2004). Statistical analysis system User's Guide. Release 9.1. SAS institute, Cary, North Carolina.

[29] Scudamore C. L., Robinson. J. Aitken R. P. and Robertson, I. S. (1992). Comparison of priming with 2 dosages of fluorogestone acetate in pessaries on the quality of embryos recovered from superovulated ewes. Theriogenology. (37): 445 456.

[30] Thompson, J. G. E., Simpson, A. C., James, R. W. and. Tervit, H. R. (1990). The application of progesterone containing CIDR devices to superovulated ewes. Theriogenology. (33): 12971304.

[31] Windorski, E. J., Schauer, C. S. Wurst, A. K. Inskeep, E. K. and Luther, J. S. (2008). Effects of melengestrol acetate and P.G. 600 on fertility in Rambouillet ewes outside the natural breeding season, Theriogenology, vol. 70, pp. 227-232. 